\title{
JM
}

Volume 7 No. 2 (Oktober 2019)

(C) The Author(s)

\section{HUBUNGAN DUKUNGAN SUAMI DAN DUKUNGAN PETUGAS KESEHATAN TERHADAP PERILAKU PEMERIKSAAN IVA DI PUSKESMAS PADANG SERAI}

\author{
RELATIONSHIP OF HUSBAND SUPPORT AND SUPPORT OF HEALTH OFFICERS \\ TO EXAMINATION BEHAVIOR OF IVA IN PADANG SERAI PUSKESMAS
}

\author{
DESI AULIA UMAMI \\ PROGRAM STUDI KEBIDANAN (DIII) \\ FAKULTAS ILMU KESEHATAN UNIVERSITAS DEHASEN BENGKULU \\ Email : desiumami@gmail.com
}

\begin{abstract}
ABSTRAK
Deteksi dini kanker leher rahim merupakan terobosan inovatif dalam pembangunan kesehatan untuk mengurangi angka kematian dan kesakitan akibat kanker leher rahim. Kanker leher rahim merupakan kanker yang banyak menyerang perempuan. Saat ini kanker serviks menduduki urutan kedua dari penyakit kanker yang menyerang di dunia dan urutan pertama di negara berkembang. Data yang diperoleh menunjukkan adanya penurunan di tahun 2012, jika dibandingkan kunjungan skrining IVA ke Puskesmas Kecamatan padang serai mengalami penurunan hampir 50\%. Tujuan penelitian mengetahui hubungan dukungan suami dan dukungan petugas kesehatan dengan pemeriksaan IVA pada wanita usia subur (WUS) di Puskesmas Kecamatan padang serai Bengkulu Tahun 2018. Metode penelitian ini jenis penelitian Kuantitatif Non Eksperimental dengan menggunakan pendekatan studi korelasi (cross sectional). Sampel pada penelitian ini diambil secara accidental sampling pada bulan desember tahun 2018 yang berjumlah 57 wanita usia subur (WUS). Hasil penelitian penulis mendapatkan wanita usia subur terbanyak tidak pernah melakukan pemeriksaan IVA yaitu 34 $(59,6 \%)$, dukungan suami terbanyak yang buruk yaitu $29(50,9 \%)$ dan dukungan petugas kesehatan yang yaitu $31(54,4 \%)$. Kesimpulannya adalah ada hubungan antara dukungan suami dengan perilaku pemeriksaan IVA, dengan P.value $=0,016(\mathrm{P}<0,05)$ dan ada hubungan antara dukungan petugas kesehatan dengan perilaku pemeriksaan IVA, dengan P.value $=0,032$ $(\mathrm{P}<0,05)$. Saran, perlu dilakukan upaya peningkatan sosialisasi dan cara penyampaian informasi yang efektif dan berkesinambungan oleh petugas puskesmas.
\end{abstract}

\section{Kata Kunci : Dukungan Suami, Petugas Kesehatan, IVA}

\begin{abstract}
Early detection of cervical cancer is an innovative breakthrough in health development to reduce mortality and morbidity due to cervical cancer. Cervical cancer is a cancer that attacks many women. Currently cervical cancer ranks second from cancer that attacks in the world and first place in developing countries. The data obtained showed a decrease in 2012, when compared to IVA screening visits to the Padang Serai District Health Center, it had decreased by almost 50\%. The purpose of this study was to find out the relationship between husband support and health staff support with IVA examination in women of childbearing age (WUS) in the
\end{abstract}


Padang Lemongrass District Health Center in Bengkulu in 2018. This research method is a Non-Experimental Quantitative study using a cross sectional study approach. The sample in this study was taken by accidental sampling in December 2018, amounting to 57 women of childbearing age (WUS). The results of the study showed that most women of childbearing age had never done an IVA examination, which was 34 (59.6\%), the most poor husband support was $29(50.9 \%)$ and the support of health workers which was $31(54.4 \%)$. The conclusion is that there is a relationship between husband's support and IVA examination behavior, with $\mathrm{P}$. value $=$ $0.016(\mathrm{P}<0.05)$ and there is a relationship between health care provider support with IVA examination behavior, and $\mathrm{P}$. value $=0.032(\mathrm{P}<0.05)$. Suggestions, efforts need to be made to increase socialization and the delivery of effective and sustainable information by puskesmas staff.

\section{Keywords: Husband Support, Health Officers, IVA}

\section{PENDAHULUAN}

Penyakit kanker leher rahim adalah masalah kesehatan yang penting bagi wanita di seluruh dunia. Kanker leher rahim merupakan keganasan yang terjadi pada leher rahim dan disebabkan oleh infeksi Human Papilloma Virus (HPV). HPV ini ditularkan lewat hubungan seksual dan infeksinya terjadi pada $75 \%$ wanita yang telah pernah berhubungan seksual. Kanker ini telah menyerang lebih dari 1,4 juta wanita di seluruh dunia ${ }^{1}$.

Kanker serviks merupakan kanker yang banyak menyerang perempuan. Saat ini kanker serviks menduduki urutan ke dua dari penyakit kanker yang menyerang perempuan di dunia dan urutan pertama bagi wanita di negara sedang berkembang. Dari data Badan Kesehatan Dunia (WHO) tahun 2009, diketahui terdapat 493.243 jiwa per tahun penderita kanker serviks baru di dunia dengan angka kematian karena kanker ini sebanyak 273.505 jiwa per tahun ${ }^{2}$.

Depkes RI, melaporkan rata-rata pencapaian skrining kanker leher rahim di 6 daerah pilot proyek untuk target 5 tahun adalah 11,64\%. Pencapaian ini masih lebih rendah dari target tahunan sebesar $20 \%$. Subdit Kanker juga menemukan prevalensi rata-rata curiga (suspect) kanker leher rahim yang terdapat di 6 kabupaten tersebut adalah $0,22 \%$ dan dari data suspect kanker leher rahim tersebut, setelah dirujuk, kasus yang benar-benar kanker leher rahim sebanyak 7 orang $(0,028 \%)$ atau 28 per 100.000 perempuan yang ber usia 30-50 tahun. Hal ini lebih tinggi dari estimasi IARC tahun 2002 sebesar 16 per 100.000 perempuan. Rendahnya cakupan deteksi dini atau screning ternyata salah satu alasan makin berkembangnya kanker leher rahim. Perempuan yang tidak melakukan skrining secara teratur memiliki risiko berkembangnya kanker leher rahim lima kali lebih tinggi dibandingkan dengan perempuan yang melakukan skrining secara teratur

Salah satu metode skrining yang sudah dikembangkan saat ini adalah teknik deteksi dini dengan metode IVA (Inspeksi Visual dengan Asam asetat). Metode ini tergolong murah, sederhana, nyaman, praktis dan tersedia di banyak sarana kesehatan. Dengan mengoleskan asam cuka (asam asetat) $5 \%$ pada serviks dan melihat reaksi perubahan warna dalam 3 menit, kelainan prakanker dapat dideteksi. Jika terdapat kelainan, maka akan tampak bercak berwarna putih yang disebut aceto white epithelium ${ }^{5}$.

Kanker leher rahim cenderung muncul pada wanita berusia 35-55 tahun. Data yang didapat dari Yayasan Kanker Indonesia, menyebutkan setiap tahunnya sekitar 500.000 wanita didiagnosa menderita kanker leher rahim dan lebih dari 250.000 meninggal dunia. Melihat data tersebut, maka tatalaksana yang komprehensif termasuk pencegahan dan deteksi dini harus dilaksanakan dengan baik ${ }^{6}$. Masih tingginya angka penderita kanker leher rahim di Indonesia disebabkan oleh 
rendahnya kesadaran wanita untuk memeriksakan kesehatan dirinya. Padahal kini, penyakit apapun sudah dapat diobati dan ditangani secara cepat, dengan pendeteksian dini yang dilakukan secara berkala sehingga dapat mengurangi resiko angka kematian ${ }^{7}$. Berdasarkan data Kemenkes RI pada Tahun 2010, didapatkan data bahwa hanya 5\% wanita yang melakukan skrining kanker serviks dengan pemeriksaan IVA. Padahal pelaksanaan skrining idealnya adalah $80 \%$. Dari jumlah penduduk wanita Indonesia, maka angka 5\% merupakan angka yang masih kecil sekali.

Pengaruh pengetahuan, sikap, kepercayaan dan tradisi Wanita Usia Subur (WUS) terhadap pemeriksaan IVA dalam upaya deteksi dini kanker serviks merupakan beberapa variabel yang akan diteliti dalam penelitian ini. Penelitian terdahulu yang dilakukan di RSU ZA Banda Aceh tahun 2008, bahwa pengetahuan mempunyai pengaruh yang signifikan terhadap perilaku pemeriksaan IVA. Hal ini menunjukkan bahwa pengetahuan memiliki pengaruh besar terhadap kesehatan. Untuk berperilaku sehat, misalnya dalam upaya deteksi dini kanker serviks, diperlukan pengetahuan dan kesadaran individu untuk melakukan pemeriksaan IVA. Pengetahuan diperoleh dari pengalaman sendiri atau pengalaman orang lain. Disamping itu kadang-kadang kepercayaan dan tradisi juga dapat mendorong atau menghambat individu untuk melakukan pemeriksaan tersebut.

Diperoleh data menunjukkan bahwa: 1) Dukungan keluarga terhadap upaya deteksi dini penyakit kanker leher rahim biasa saja, bahkan terdapat 17 dari 30 responden menyatakan tanggapan yang buruk tentang persepsi keluarga (suami) terhadap upaya deteksi dini penyakit kanker leher rahim. 2) Tanggapan wanita usia subur tentang pelayanan kesehatan terhadap upaya deteksi dini penyakit kanker leher rahim juga biasa saja dan kecenderungan sama antara pelayanan yang baik dan buruk, dan terdapat 18 dari 30 responden yang menyatakan bahwa petugas kesehatan tidak pernah menjelaskan terkait kanker leher rahim. 3) Tanggapan wanita usia subur dominan 21 dari 30 kurang baik untuk membuat keputusan mengikuti kegiatan deteksi dini baik pada aspek penyuluhan maupun pemeriksaan IVA. Dari fenomena permasalahan diatas, peneliti merasa tertarik untuk melakukan penelitian terkait "Hubungan Dukungan Suami dan Dukungan Petugas Kesehatan dengan Pemeriksaan IVA pada Wanita Usia Subur (WUS) di Puskesmas Kecamatan padang serai Bengkulu Tahun 2018”.

Tujuan dari penelitian ini adalah Mengetahui hubungan Dukungan Suami dan Dukungan Petugas Kesehatan dengan Pemeriksaan IVA pada Wanita Usia Subur (WUS) di Puskesmas Kecamatan padang serai Bengkulu Tahun 2018"

\section{METODE PENELITIAN}

Desain penelitian merupakan suatu strategi penelitian dalam mengidentifikasi permasalahan sebelum perencanaan akhir pengumpulan data dan digunakan untuk mendefinisikan struktur dimana penelitian dilaksanakan $^{12}$. Desain penelitian yang digunakan adalah jenis penelitian Kuantitatif Non Eksperimental dengan menggunakan pendekatan studi korelasi (cross sectional) yaitu pengumpulan data penelitian yang dilaksanakan sekaligus pada suatu saat. Tujuan menggunakan penelitian korelasi mengkaji hubungan dua variabel dukungan suami dan dukungan petuas kesehatan dengan pemeriksaan IVA (Inspeksi Visual dengan Asam Asetat). Populasi merupakan keseluruhan objek penelitian atau objek yang diteliti tersebut ${ }^{11}$. Populasi dalam penelitian ini adalah seluruh wanita (usia 30-45 tahun) yang telah menikah dan sedang berkunjung di Puskesmas Kecamatan padang serai Bengkulu pada Bulan Juli-Oktober Tahun 2018 yang berjumlah 138 Wanita Usia Subur (WUS). Sampel adalah bagian atau wakil populasi yang akan diteliti. Sedangkan menurut Hidayat sampel adalah bagian populasi yang diteliti atau sebagian dari karakteristik yang dimiliki oleh populasi. 
Sampel yang diambil dengan menggunakan accidental sampling, hakikat dari pengambilan sampel secara sistematis ini adalah menentukan sampel karena kebetulan bertemu, yaitu WUS yang berkunjung pada bulan desember tahun 2018 yang berjumlah 57 Wanita Usia Subur (WUS).

Alat pengumpulan data yang digunakan dalam mengumpulkan data ini adalah kuesioner yang terdiri dari tiga bagian yaitu kuesioner A berisikan tentang data demografi responden, meliputi pendidikan, jumlah anak, Umur menikah atau memulai aktifitas seksual usia muda dan perilaku pemeriksaan IVA, kuesioner B berisikan pernyataan mengenai dukungan suami yang diberikan pada Wanita Usia Subur (WUS) yang berjumlah 11 pernyataan dari 1-11 dengan menggunakan metode check list ( ) dengan pilihan jawaban YA dan TIDAK, kuesioner $\mathrm{C}$ berisikan pernyataan tentang dukungan petugas kesehatan yang berjumlah 11 pernyataan dari 1-11 dengan menggunakan metode check list ( ) dengan pilihan jawaban YA atau TIDAK.

Pada penelitian ini peneliti memeriksa satu per satu data yang telah di entry mengubah setiap kekeliruan atau kesalahan yang terjadi pada saat melakukan entry data. Data bersih merupakan Setelah semua kuisioner terisi penuh dan benar, serta sudah melewati pengkodean, maka selanjutnya adalah memproses data agar data yang sudah di-entry data dan koesioner ke paket program komputer.

Dalam penelitian kesehatan uji signifikan dilakukan dengan menggunakan batas kemaknaan (alpha) $=0,05$ dan 95\% confidence interval. Dengan ketentuan bila: $\mathrm{P}$ value $\leq 0,05$ berarti Ho ditolak (P value $\leq \alpha)$. Uji statistik menunjukkan adanya hubungan yang signifikan. $\mathrm{P}$ value $>0,05$ berarti Ho gagal ditolak $(\mathrm{P}$ value $>\alpha)$. Uji statitik menunjukkan tidak ada hubungan yang signifikan.

Uji Chi Square digunakan karena variabel dependen dan independen dalam penelitian ini bersifat katagorik. penelitian ini menggunakan batas bermakna secara statistik sebesar 5\%, sehingga jika diperoleh nilai $\mathrm{p}>$ alpha, maka hasil perhitungan statistiknya tidak bermakna, artinya tidak ada hubungan signifikan antara variabel dependen dengan variabel independen. sebaliknya jika diperoleh nilai $\mathrm{p} \leq$ alpha, maka hasil perhitungan statistiknya bermakna, artinya ada hubungan yang signifikan antara variabel dependen dengan variabel independen.

Pengumpulan data dalam bentuk tertulis mulai dari pengambilan sampel, pelaksanaan pengumpulan data dan sampai hasil analisis yang berupa informasi dari pengumpulan data tersebut dan penyajian data secara tabular yaitu memberikan keterangan berbentuk angka. Jenis yang digunakan dalam penelitian ini adalah master tabel dan tabel distribusi frekuensi. Dimana data disusun dalam baris dan kolom dengan sedemikian rupa sehingga dapat memberikan gambaran.

\section{HASIL PENELITIAN}

\section{Table 1. Distribusi Frekuensi}

\begin{tabular}{cccc}
\hline Variabel & Kriteria & N & \% \\
\hline \multirow{2}{*}{$\begin{array}{c}\text { Perilaku } \\
\text { pemeriksaan IVA }\end{array}$} & $\begin{array}{c}\text { tidak periksa } \\
\text { IVA }\end{array}$ & 34 & 59,6 \\
\cline { 2 - 4 } periksa IVA & 23 & 40,4 \\
\hline Dukungan suami i & buruk & 29 & 50,9 \\
\cline { 2 - 4 } & baik & 28 & 49,1 \\
\hline $\begin{array}{c}\text { Dukungan } \\
\text { petugas } \\
\text { kesehatan }\end{array}$ & buruk & 31 & 54,4 \\
\cline { 2 - 4 } & baik & 26 & 45,6 \\
\hline
\end{tabular}

Sumber : olahan data SPSS tahun 2018

Berdasarkan tabel 1 dapat dilihat bahwa distribusi responden berdasarkan Perilaku Pemeriksaan IVA pada Wanita Usia Subur terbanyak tidak pernah melakukan pemeriksaan IVA yaitu $34(59,6 \%)$ Wanita Usia Subur. Berdasarkan hasil penelitian distribusi responden berdasarkan Dukungan Suami pada Wanita Usia Subur (WUS) terbanyak dengan dukungan yang buruk pada Wanita Usia Subur (WUS) untuk melakukan pemeriksaan IVA yaitu 29 (50,9\%). Berdasarkan hasil penelitian distribusi responden berdasarkan Dukungan Petugas Kesehatan pada Wanita Usia Subur (WUS) 
terbanyak dengan dukungan yang buruk untuk melakukan pemeriksaan IVA yaitu 31 $(54,4 \%)$.

Berdasarkan table 2 diatas menjelaskan analisa hubungan antara dukungan suami dengan perilaku pemeriksaan IVA oleh Wanita Usia Subur (WUS) diperoleh dari 57 responden yang dengan dukungan suami yang buruk sebagian besar Wanita Usia Subur (WUS) tidak melakukan pemeriksaan IVA yaitu 22 Wanita Usia Subur (38,6\%), sedangkan dari 29 Wanita Usia Subur yang melakukan pemeriksaan IVA terdapat 16 Wanita Usia Subur $(28,1 \%)$ dengan dukungan suami yang baik. Dari hasil uji statistik diperoleh p.value $=0,016(p<0,05)$, maka dapat disimpulkan bahwa ada hubungan antara Dukungan Suami dengan Perilaku Pemeriksaan IVA pada Wanita Usia Subur (WUS) di Puskesmas Kecamatan PADANG SERAI Jakarta Timur Tahun 2018. Di peroleh nilai $\mathrm{OR}=4,190$ yang artinya Wanita Usia Subur yang memiliki dukungan suami yang buruk mempunyai peluang 4,190 kali untuk tidak melakukan pemeriksaan IVA dibandingkan dengan yang mempunyai dukungan suami yang baik.

Analisa hubungan antara dukungan petugas kesehatan dengan perilaku pemeriksaan IVA oleh Wanita Usia Subur (WUS) diperoleh dari 31 responden yang dengan dukungan petugas kesehatan yang buruk sebagian besar Wanita Usia Subur (WUS) tidak melakukan pemeriksaan IVA yaitu 20 Wanita Usia Subur (35,1\%), sedangkan dari 26 Wanita Usia Subur yang melakukan pemeriksaan IVA terdapat 12 Wanita Usia Subur (35,9\%) dengan dukungan petugas kesehatan yang baik. Dari hasil uji statistik diperoleh p.value $=0,032(\mathrm{p}<0,05)$, maka dapat disimpulkan bahwa ada hubungan antara Dukungan Petugas Kesehatan dengan Perilaku Pemeriksaan IVA pada Wanita Usia Subur (WUS) di Puskesmas Kecamatan PADANG SERAI Jakarta Timur Tahun 2018.Di peroleh nilai $\mathrm{OR}=1,558$ yang artinya Wanita Usia Subur yang memiliki dukungan petugas kesehatan yang buruk mempunyai peluang 1,558 kali untuk tidak melakukan pemeriksaan IVA dibandingkan dengan yang mempunyai dukungan petugas kesehatan yang baik.

Table 2. Hubungan Dukungan Suami dan Dukungan Petugas Kesehatan dengan Perilaku Pemeriksaan IVA pada Wanita Usia Subur (WUS) di Puskesmas Kecamatan PADANG SERAI Jakarta Timur Tahun 2018.

\begin{tabular}{|c|c|c|c|c|c|c|c|c|}
\hline \multirow[b]{3}{*}{ Variabel } & \multicolumn{6}{|c|}{ Perilaku Pemeriksaan IVA } & \multirow{3}{*}{$\begin{array}{c}\text { P } \\
\text { val } \\
\text { ue }\end{array}$} & \multirow{3}{*}{ OR } \\
\hline & \multicolumn{2}{|c|}{$\begin{array}{c}\text { Tidak } \\
\text { Perikasa } \\
\text { IVA } \\
\end{array}$} & \multicolumn{2}{|c|}{$\begin{array}{c}\text { Periksan } \\
\text { IVA }\end{array}$} & \multicolumn{2}{|r|}{$\mathbf{S}$} & & \\
\hline & $\mathbf{N}$ & $\%$ & $\mathbf{N}$ & $\%$ & $\mathbf{N}$ & $\%$ & & \\
\hline \multicolumn{9}{|c|}{$\begin{array}{l}\text { Dukungan } \\
\text { suami }\end{array}$} \\
\hline buruk & 22 & 38,6 & 7 & 12,3 & $\begin{array}{l}2 \\
9\end{array}$ & 50,9 & \multirow{2}{*}{$\begin{array}{l}0,0 \\
16\end{array}$} & \multirow{2}{*}{$\begin{array}{c}4,19 \\
0\end{array}$} \\
\hline Baik & 12 & 21 & $\begin{array}{l}1 \\
6\end{array}$ & 28,1 & $\begin{array}{l}2 \\
8\end{array}$ & 49,1 & & \\
\hline \multicolumn{9}{|c|}{$\begin{array}{c}\text { Dukungan petugas } \\
\text { Kesehatan }\end{array}$} \\
\hline buruk & 20 & 35,1 & 11 & 19,3 & $\begin{array}{l}3 \\
1\end{array}$ & 54,4 & 0,0 & 1,55 \\
\hline baik & 14 & 24,5 & $\begin{array}{l}1 \\
2\end{array}$ & 21,1 & $\begin{array}{l}2 \\
6\end{array}$ & 45,6 & 32 & 8 \\
\hline
\end{tabular}

\section{PEMBAHASAN}

\section{Dukungan Suami}

Suami adalah pasangan hidup istri (ayah dari anak-anak), suami mempunyai suatu tanggung jawab yang penuh dalam suatu keluarga tersebut dan suami mempunyai peranan yang penting, dimana suami sangat dituntut bukan hanya sebagai pencari nafkah akan tetapi suami sebagai motivator dalam berbagai kebijakan yang akan di putuskan termasuk merencanakan keluarga. Sumber dukungan internal (suami) merupakan aspek yang penting untuk peningkatan kesehatan reproduksi dari istri. Dukungan suami dalam upaya pencegahan kanker serviks dapat diwujudkan melalui berbagai tindakan misalnya dengan memberikan informasi sesuai dengan yang diketahuinya kepada istrinya. Karena biasanya istri mempercayai 
dan mematuhi suaminya. Menurut Cohen dan Syme (1996) dalam frida dukungan sosial adalah suatu yang bermanfaat untuk individu yang diperoleh dari orang lain yang dapat dipercaya, sehingga seseorang tahu bahwa ada orang lain yang memperhatikan, menghargai dan mencintainya.

Hasil uji statistik pada analisis bivariat dengan uji chi square pada tingkat kepercayaan $95 \%$, didapat nilai p.value = $0,016(\mathrm{p}<0,05)$. Artinya, ada hubungan antara dukungan suami dengan perilaku pemeriksaan IVA oleh Wanita Usia Subur (WUS). Dari 57 responden yang dengan dukungan suami yang buruk sebagian besar Wanita Usia Subur (WUS) tidak melakukan pemeriksaan IVA yaitu 22 Wanita Usia Subur (38,6\%), sedangkan dari 29 Wanita Usia Subur yang melakukan pemeriksaan IVA terdapat 16 Wanita Usia Subur (28,1\%) dengan dukungan suami yang baik. Di peroleh juga nilai $\mathrm{OR}=4,190$ yang artinya Wanita Usia Subur yang memiliki dukungan suami yang buruk mempunyai peluang 4,190 kali untuk tidak melakukan pemeriksaan IVA dibandingkan dengan yang mempunyai dukungan suami yang baik.

Dalam kaitannya dengan peran sebagai pemberi dukungan, melihat bahwa salah satu peran dari pemberdaya masyarakat adalah untuk menyediakan dan mengembangkan dukungan terhadap warga yang mau terlibat dalam struktur dan aktivitas komunitas tersebut. Dukungan itu sendiri tidak selalu bersifat ekstrinsik ataupun materil, tetapi dapat juga bersifat instrinsik seperti pujian, penghargaan dalam bentuk kata-kata, ataupun sikap dan perilaku yang menunjukkan dukungan dari pelaku perubahan terhadap apa yang dilakukan oleh masyarakat. Seperti menyediakan waktu bagi wanita usia subur bila mereka ingin berbicara dengannya guna membahas permasalahan yang mereka hadapi.

Penelitian penelitian ini juga sejalan dengan penelitian yang pernah dilakukan oleh Elinna Yuli dengan judul "Hubungan Dukungan Suami pada Wanita Pasangan Usia Subur (Pus) Tentang Kanker Leher Rahim
(KLR) Dan Program Inspeksi Visual Asetat (IVA) Terhadap Pemanfaatan Pelayanan IVA di Wilayah Kerja Puskesmas Bandar Khalifah Kecamatan Percut Sei Tuan Kabupaten Deli Serdang Tahun 2010". Hasil uji kai kuadrat menunjukkan bahwa terdapat perbedaan yang signifikan antara Dukungan Suami pada Wanita Pasangan Usia Subur (PUS) Tentang Kanker Leher Rahim (KLR) dan Program Inspeksi Visual Asetat (IVA) dengan Pemanfaatan Pelayanan IVA. Hal ini ditunjukkan dari nilai $p=0,000(p<0,05)$.

\section{Dukungan Petugas Kesehatan}

Dukungan adalah menyediakan sesuatu untuk memenuhi kebutuhan orang lain. Dukungan juga dapat diartikan sebagai memberikan dorongan/motivasi atau semangat dan nasihat kepada orang lain dalam situasi pembuat keputusan. Tenaga Kesehatan adalah setiap orang yang mengabdikan diri dalam kesehatan serta memiliki pengetahuan dan atau ketrampilan melalui pendidikan dibidang kesehatan yang untuk jenis tertentu memerlukan kewenangan untuk melakukan upaya kesehatan. ${ }^{8}$ Perilaku kesehatan seseorang sangat dipengaruhi oleh tenaga kesehatan. Seseorang yang sudah mengetahui manfaat dari sebuah perilaku yang sehat dapat terhalang karena sikap dan tindakan tenaga kesehatan yang tidak mendukung dan memotivasi individu untuk melakukan sebuah perilaku kesehatan, khususnya pemberian makanan pada balita. Selain itu, banyak ibu yang kurang memahami cara pemberian makanan yang sehat kepada balita, sehingga sangat dibutuhkan peran dan dukungan dari tenaga kesehatan.

Hasil uji statistik pada analisis bivariat dengan uji chi square pada tingkat kepercayaan $95 \%$, didapat nilai p.value $=$ $0,032(\mathrm{p}<0,05)$. Artinya, ada hubungan antara dukungan petugas kesehatan dengan perilaku pemeriksaan IVA oleh Wanita Usia Subur (WUS).

Dari 103 responden yang dengan dukungan petugas kesehatan yang buruk 
sebagian besar Wanita Usia Subur (WUS) tidak melakukan pemeriksaan IVA yaitu 20 Wanita Usia Subur, sedangkan dari 26 Wanita Usia Subur yang melakukan pemeriksaan IVA terdapat 12 Wanita Usia Subur $(35,9 \%)$ dengan dukungan petugas kesehatan yang baik.

Di peroleh juga nilai $\mathrm{OR}=1,558$ yang artinya Wanita Usia Subur yang memiliki dukungan petugas kesehatan yang buruk mempunyai peluang 1,558 kali untuk tidak melakukan pemeriksaan IVA dibandingkan dengan yang mempunyai dukungan petugas kesehatan yang baik.

Perilaku kesehatan seseorang sangat dipengaruhi oleh tenaga kesehatan. Seseorang yang sudah mengetahui manfaat dari sebuah perilaku yang sehat dapat terhalang karena sikap dan tindakan tenaga kesehatan yang tidak mendukung dan memotivasi individu untuk melakukan sebuah perilaku kesehatan, khususnya pemberian makanan pada balita. Selain itu, banyak ibu yang kurang memahami cara pemberian makanan yang sehat kepada balita, sehingga sangat dibutuhkan peran dan dukungan dari tenaga kesehatan

Dukungan adalah menyediakan sesuatu untuk memenuhi kebutuhan orang lain. Dukungan juga dapat diartikan sebagai memberikan dorongan/motivasi atau semangat dan nasihat kepada orang lain dalam situasi pembuat keputusan. Tenaga Kesehatan adalah setiap orang yang mengabdikan diri dalam kesehatan serta memiliki pengetahuan dan atau ketrampilan melalui pendidikan dibidang kesehatan yang untuk jenis tertentu memerlukan kewenangan untuk melakukan upaya kesehatan (UndangUndang RI No. 36 Tahun 2009 tentang kesehatan).

Menurut Green yang dikutip, dukungan tenaga kesehatan merupakan salah satu faktor yang sangat menentukan dalam menimbulkan sebuah perilaku kesehatan. Gottlieb, berpendapat dukungan petugas kesehatan terdiri dari informasi atau nasehat verbal dan non verbal, bantuan nyata, atau tindakan yang diberikan oleh keakraban sosial atau dapat dikatakan karena adanya kehadiran mereka mempunyai manfaat emosional atau efek perilaku bagi pihak penerimanya. Dukungan tenaga kesehatan masuk didalam lingkup dukungan sosial, dimana yang dimaksud dari dukungan social adalah bentuk dukungan dan hubungan yang baik untuk memberikan kontribusi penting pada kesehatan. Dukungan petugas kesehatan yang dibutuhkan adalah berupa dukungan informasional yang mendasari tindakan.

Dalam membedakan dukungan petugas kesehatan ke dalam empat bentuk yaitu dukungan informasi (informational) dimana tenaga kesehatan memberikan informasi, penjelasan tentang situasi dan segala sesuatu yang berhubungan dengan masalah yang sedang dihadapi oleh seseorang. Mengatasi permasalahan dapat digunakan seseorang dengan memberikan nasehat, anjuran, petunjuk dan masukan, kedua dukungan penilaian (appraisal) dimana tenaga kesehatan berfungsi sebagai pemberi umpan balik yang positif, menengahi penyelesaian masalah yang merupakan suatu sumber dan pengakuan identitas individual. Keberadaan informasi yang bermanfaat dengan tujuan penilaian diri serta penguatan (pembenaran). Ketiga dukungan instrumental (instrumental) dimana tenaga kesehatan merupakan suatu sumber bantuan yang praktis dan konkrit. Bantuan mencakup memberikan bantuan yang nyata dan pelayanan yang diberikan secara langsung bisa membantu seseorang yang membutuhkan, seperti: pemberian makanan secara langsung (bubur, susu, roti, telur dan lain-lain), dan yg terakhir dukungan emosional (emotional) dimana tenaga kesehatan berfungsi sebagai suatu tempat berteduh dan beristirahat, yang berpengaruh terhadap ketenangan emosional, mencakup pemberian empati, dengan mendengarkan keluhan, menunjukkan kasih sayang, kepercayaan, dan perhatian. Dukungan emosional akan membuat seseorang merasa lebih dihargai, nyaman, aman dan disayangi.

Peran dan tanggung jawab petugas kesehatan dalam kesehatan reproduksi khususnya pada pemeriksaan IVA sangat 
berpengaruh terhadap kesehatan pada wanita di usia subur. Hal-hal penting seperti apa yang dilakukan jika muncul gejala-gejala kanker serviks akan memudahkan para wanita dalam menghadapi masa ini. Peran dan dukungan petugas kesehatan dimaksudkan untuk memberikan materi, emosi ataupun informasi yang berpengaruh terhadap pengetahuan dan kesiapan wanita menghadapi berbagai kemungkinan buruknya kesehatan reproduksi wanita di usia subur.

Peran anggota masyarakat (kader) adalah sebagai motivator atau penyuluh kesehatan yang membantu para petugas untuk meningkatkan kesadaran masyarakat tentang perlunya hidup sehat dan memotivasi mereka untuk melakukan tindakan pencegahan penyakit dengan menggunakan sarana kesehatan yang ada. Disamping kader kesehatan, masyrakat memiliki pula kelompok yang berpotensi untuk membantu menyehatkan penduduk yaitu para pengobatan tradisional.

Paramedis dan medis yang kompeten adalah yang memiliki sertifikat pelatihan IVA dan mampu melakukan pemeriksaan IVA dengan baik sesuai dengan prosedur tetap merupakan salah satu faktor pendorong yang mempunyai hubungan dengan tingginya cakupan IVA. Salah satu kendala dalam pelaksanaan deteksi dini kanker serviks adalah karena kurangnya SDM sebagai pelaku deteksi dini, hal ini dapat mengurangi motivasi WUS untuk melakukan deteksi dini.

Sikap paramedis dan medis memiliki hubungan yang signifikan dengan cakupan IVA. Semakin positif sikap paramedis dan medis mempunyai hubungan dengan tingginya cakupan IVA. Sikap positif ini ditunjukkan dalam rangkaian pernyataaan yang menyatakan hal-hal positif dan mendukung mengenai suatu obyek dalam hal ini program deteksi dini kanker serviks dengan pemeriksaan IVA, begitu pula sebaliknya.

Semakin seringnya paramedis dan medis melakukan pemeriksaan IVA baik itu di Puskesmas maupun di praktek swasta mandiri juga merupakan perilaku yang aktif yang dikerjakan oleh paramedis dan medis. Prosedur pembentukan perilaku yang positif maupun negatif menurut Skinner, dilihat dari bagaimana seorang paramedis dan medis tersebut melakukan identifikasi tentang halhal yang terkait dengan kanker serviks dan IVA pada WUS, melakukan analisis serta melakukan tindakan pemeriksaan IVA secara prosedural. Semakin sering prosedural tersebut dilakukan akan membentuk perilaku yang lebih aktif.

Notoatmodjo berpendapat dalam diri individu sebenarnya terdapat suatu dorongan yang didasarkan pada kebutuhan, perasaan, perhatian dan kemampuan untuk mengambil suatu keputusan pada suatu saat terhadap suatu perubahan atau stimulus. Proses dalam tahapan ini sesungguhnya masih bersifat tertutup, tetapi sudah merupakan keadaan yang disebut sikap. Bila terus menerus diarahkan, diberikan informasi yang benar, maka pada suatu saat akan meningkatkan menjadi lebih terbuka dan berwujud pada suatu reaksi yang berupa perilaku. Demikian pula dengan wanita usia subur, bila pemberian informasi dilakukan dengan terus menerus dan informasi yang diberikan benar kepada mereka, maka mereka akan dapat mewujudkannya dalam bentuk perilaku yaitu melakukan deteksi dini kanker serviks (pemeriksaan pap smear).

Penelitian ini sejalan dengan penelitian Pujiyono pada tahun 2009, yang menunjukan bahwa pengetahuan, sikap, praktik, peranan petugas kesehatan dan peranan keluarga termasuk kategori kurang. Variabel yang berhubungan secara signifikan dengan pemanfaatan Puskesmas dalam Pemeriksaan IVA yaitu peran petugas kesehatan dan peran keluarga. Faktor yang paling dominan berhubungan dengan praktik pemanfaatan Puskesmas dalam Pemeriksaan IVA adalah peranan petugas kesehatan.

Penelitian ini juga sejalan dengan penelitian terkait yang dilakukan oleh Rodiyah Ningsih dengan judul "Hubungan Petugas Kesehatan Terhadap Pemeriksaan IVA Untuk Mendeteks Kanker Leher Rahim di Puskesmas Medan Area Selatan Tahun 
2009”. Berdasarkan hasil penelitian bahwa kategori Dukungan Petugas Kesehatan pada responden yang periksa IVA, dengan Dukungan Petugas Kesehatan yang baik ada 23,3\%, yang Dukungan Petugas Kesehatan yang sedang $76,7 \%$ dan yang Dukungan Petugas Kesehatan yang buruk yaitu 49,1\%.

\section{KESIMPULAN}

Pemberian informasi sangat diperlukan karena komunikasi dapat mengkondisikan faktor kurangnya pengetahuan dan sikap masyarakat terhadap kesehatan dan penyakit, mereka berperilaku sesuai dengan nilai-nilai kesehatan $^{11}$. Untuk itu diperlukan komunikasi yang efektif dari petugas kesehatan. Sebagai komunikator petugas seharusnya memberikan informasi secara jelas kepada pasien atau masyarakat dalam hal ini wanita usia subur. Sebagai komunikator petugas seharusnya memberikan informasi secara jelas kepada wanita usia subur tersebut secara lengkap sehingga dapat meningkatkan pengetahuan dan pemahamannya tentang pencegahan dini kanker serviks dengan melakukan pameriksaan pap smear.

\section{SARAN}

Diharapkan kepada Peneliti selanjutnya untuk lebih mengembangkan penelitian tentang Dukungan Suami dan Dukungan Petugas Kesehatan terhadap Pemeriksaan IVA dengan menggunakan desain penelitian yang berbeda.

\section{DAFTAR PUSTAKA}

Arikunto, Suharsimi. Manajemen Penelitian. Jakarta. Rineka Cipta; 2008.

Bobak. Irene M. Buku Ajar Keperawatan Maternitas. Cetakan 2. Jakarta: EGC; 2009.

Budiharto. Dukungan pasangan dalam perawatan kesehatan. Jakarta. ANDI; 2008.

Depkes RI. Undang-Undang no 36 Tahun 2009 Tentang Kesehatan. Jakarta; 2010.
Depkes RI. Profil Pengendalian Penyakit \& Penyehatan Lingkungan. Ditjen PP \& PL, Jakarta; 2008.

Emilia Ova. Bebas ancaman kanker serviks. Yogyakarta: Media pressindo; 2010

Female Cancer Programme. Program Pencegahan Kanker Seviks, See and Treat: Buku Acuan. Kerjasama dengan Fakultas Kedokteran se Indonesia, Jakarta; 2008.

Frida. Pengaruh Dukungan Keluarga Dan Sumber Informasi Terhadap Perilaku Wanita Usia Subur Dalam Deteksi Dini Kanker Serviks Di Kecamatan Medan Selayang Tahun 2012. [TESIS]. Program Studi S2 Ilmu Kesehatan Masyarakat Fakultas Kesehatan Masyarakat Universitas Sumatera Utara. Diperoleh dari http://repository.usu.ac.id/handle/12345 6789/33835, diakses pada tanggal 1 Oktober 2018

Hanifah, Wiknjosastro. Ilmu Kebidanan. Jakarta : Yayasan Bina Pustaka Sarwono Prawirohardjo; 2007.

Hidayat, A. Aziz Alimul. Metode penelitian Kebidanan dan teknik analisis data. Jakarta. Salemba Medika; 2007.

Hastono, S.P. Analisa data Kesehatan. Jakarta: Rineka Cipta; 2007.

Heni Sumastri. Hubungan antara perilaku dengan deteksi dini Ca. Cervix Menggunakan IVA Test Di Puskesmas Basuki Rahmat Palembang Tahun 2018. Poltekkes Palembang. 2018

Maharsie, Lesse. Hubungan pengetahuan ibu tentang kanker serviks dengan keikutsertakan ibu melakukan IVA test di Kelurahan Jebres. Surakarta. Jurnal. Surkarta: STIK 'Aisyiyah Surakarta. 2012.

Marimbi,Hanum. tumbuh kembang, status gizi dan imunisasi dasar pada balita. Yogyakarta. Nuba Medika; 2010.

McKenzie. Kesehatan Masyarakat Suatu Pengantar. Jakarta: EGC; 2008.

Nadia. Insidensi kejadian Ca. Cervix di indonesia. Jurnal. Jakarta:FKUI. 2009.

Nurtini, Ade. Hubungan antara tingkat 
pengetahuan ibu dengan cakupan IVA di puskesmas Denpasar. Jurnal. Bali: Universitas Denpasar. 2012.

Nugroho Taufan. Kesehatan Wanita Gender dan Permasalahannya. Yogyakarta: Nuha Medika; 2010.

Nurhasanah. Pengaruh karakteristik dan Perilaku Pasangan Usia Subur (PUS) terhadap Pemeriksaan IVA di RSUZA Banda Aceh; 2008.

Notoatmodjo, Soekidjo. Promosi Kesehatan; Teori dan Aplikasi. Jakarta. Rineka Cipta; 2010.

Pinem,Saroha. Kesehatan reproduksi dan kontrasepsi. Jakarta: Trans Info Media; 2009

Setiadi. Waspadai 4 Kanker Ganas Pembunuh Wanita. Yogyakarta: Penerbit ANDI; 2009

Sudiharto. Asuhan Keperawatan keluarga dengan pendekatan keperawatan transkultural. Editor. Esty Whayuningsih-jakarta. EGC; 2007.

Taylor E, Shellley. Psikologi Sosial. Jakarta: Kencana Predana Media; 2009. 